\title{
Utilization of Labview in MIMO Control for Multiple Tanks Level Measurement System
}

\author{
Kalaiselvi B, Vijayan T, Sridharraja D, Abinethri R
}

\begin{abstract}
The modernisation of the existing device of facts acquisition machine in procedure manage is upgraded to the recent technologies for running the technique station. This paper offers the perspectives on the prevailing 3 tank structures installation is used for controlling the levels of two interacting systems. Liquid degree control has a completely big software domain in enterprise circulate over; the 3 tank system is one of the most broadly used experiments in laboratory \& studies institutes. The measurement of business technique level parameter is one of the wonderful importances in manner manage. the extent of liquids may additionally have an effect on each the stress and fee of float in and out of the tank. subsequently, the excellent can be affected. automated manage applications would require control indicators for operation of actuation. stage transmitter is used to measure level of the tank. in this gadget the level in the process tank is sensed the usage of a degree transmitter and the corresponding present day output being measured and managed with the aid of the use of statistics acquisition gadget. [1],[3],[5]

Keywords : Closed loop, Cascade control, LabView, Virtual Instrumentation
\end{abstract}

\section{INTRODUCTION}

Industrial control systems are used in equipment or machinery for industrial productionor control.Two types of control systems arecommon, open loop control systems and closed loop control systems. There are two common classes of control system, open loop control systems and closed loop control systems. In open circle control framework yield is created dependent on information sources. In shut circle control frameworks current yield is contemplated and rectifications are made dependent on criticism. [2 ], [4],[6]

A closed loop system is also called a feedback control system. Procedure control is the demonstration of controlling a last controller component to change the controlled variable to keep up the procedure variable at an ideal set point .The controlled variable is a proportion of asset being encouraged into the procedure. Final control element is the device that changes the value of the manipulated variable. The controller output is the signal from the controller to the final control element. The process variable is the measure of the process output that changes in response to changes in the manipulated

Revised Manuscript Received on August 22, 2019.

B.Kalaiselvi, Department of EIE, Bharath Institute of Higher education and research, Tamilnadu, India. Email: kalaiselvi.eie@bharathuniv.ac.in

Sridhar Raja D Department of EIE, Bharath Institute of Higher Education and Research, Tamilnadu, India. Email: sridharraja.eie@bharathuniv.ac.in

T.Vijayan, Department of EIE,Bharath Institute of Higher education and research, Tamilnadu, India. Email: vijayan.eie@ bharathuniv.ac.in

R.Abinethri, Department of EIE, Bharath Institute of Higher education and research, Tamilnadu, India. Email: abi.eie@bharathuniv.ac.in variable. The set point is the value at which we wish to maintain the process variable at.

\section{PROPOSED EXPERIMENTAL SYSTEM}

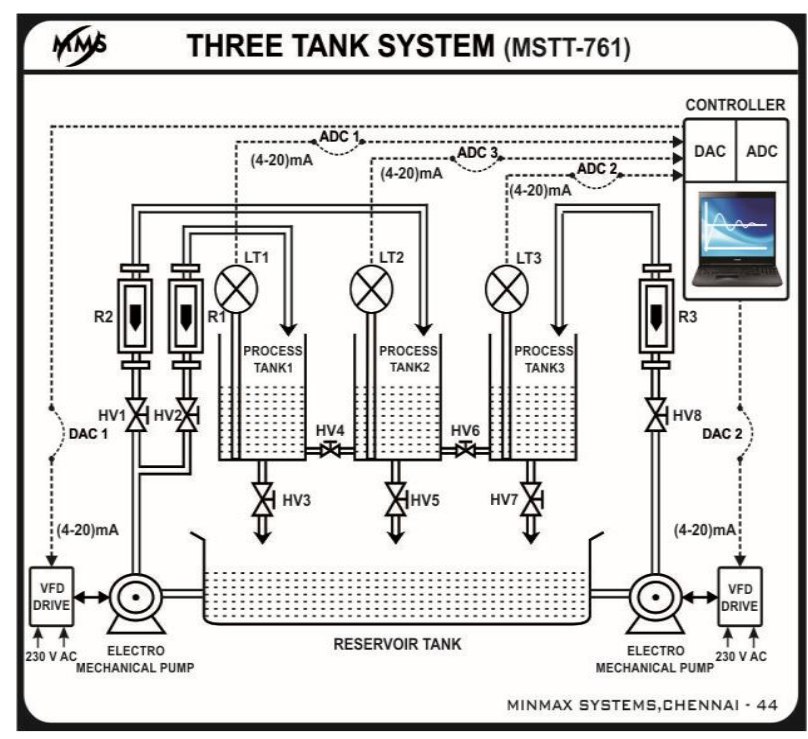

Figure.1Proposed system in real time

This the experimental device used the Closed loop block diagram is shown within the Labview screen advanced according to the proposed system. In cascade there are two loops one the grasp whose set point does now not changes so often whereas the output of the master loop is going to be the set factor of the slave loop consequently the designing of slave loop controller performs a vital position in bringing the 2 tanks to the specified set point.

DAQ: The statistics acquisition device which acquires all of the facts from the actual time three tank system station which is used to interface all the analog inputs from the actual time procedure and processed by the controller designed for the stableness of the proposed device and the controller output is given to the very last control element through DAC and the cutting-edge to pressure converter.

Cascade control: The cascade analyser block diagram is designed as shown inside the figure; the cascade control is basically have primary and secondary loops whose controller are master and slave controller. grasp's set factor does now not range swiftly in which because the slave set factor varies hastily. notwithstanding variations inside the set point the controller design is a tedious procedure. [7],[9], [11] 


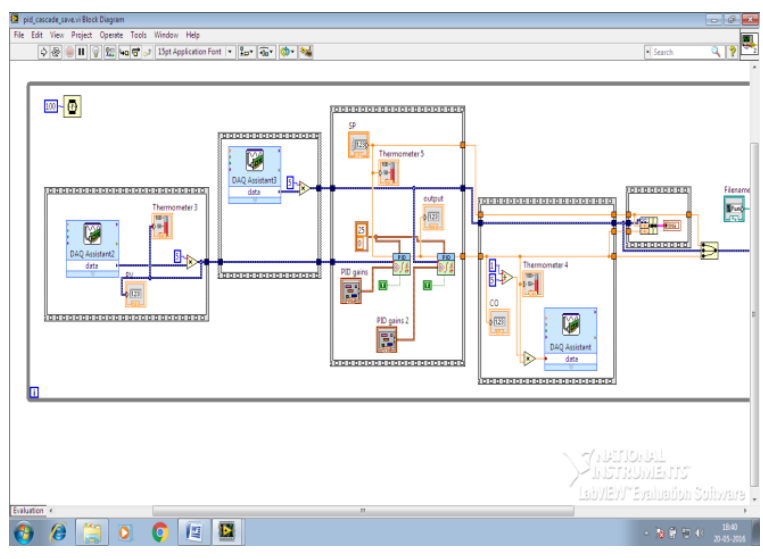

Figure2. Schematic of Cascade control system

After building the block diagram in LabViewthe constantly run operation is selected within the record menu. The Cascade connection may be viewed from the Labview window panel as shown in fig 3. [8],[10], [12]

The final manage detail is the pneumatic manage valve. This manage valve is managed via the manipulated variable given from the controller through modern-day to strain converter. [13], [15], [17]

\section{RESULTS AND CONCLUSIONS}

The process data is tabulated using Excel format and the process running window also shows the level of the two tanks virtually also as shown in the figure. [14],[16], [18]

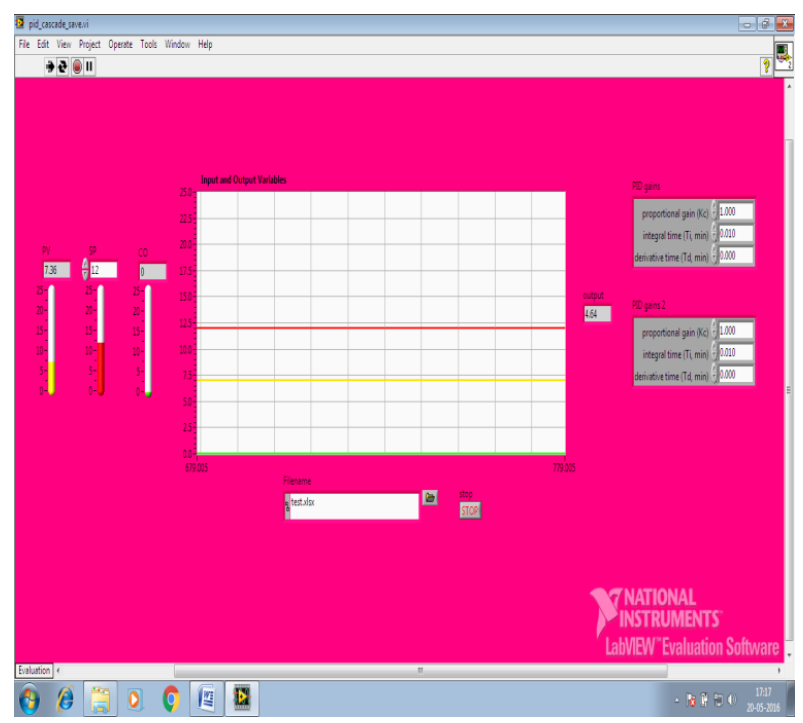

Figure.3Window in virtual set up using LabView

Three tank system consists of

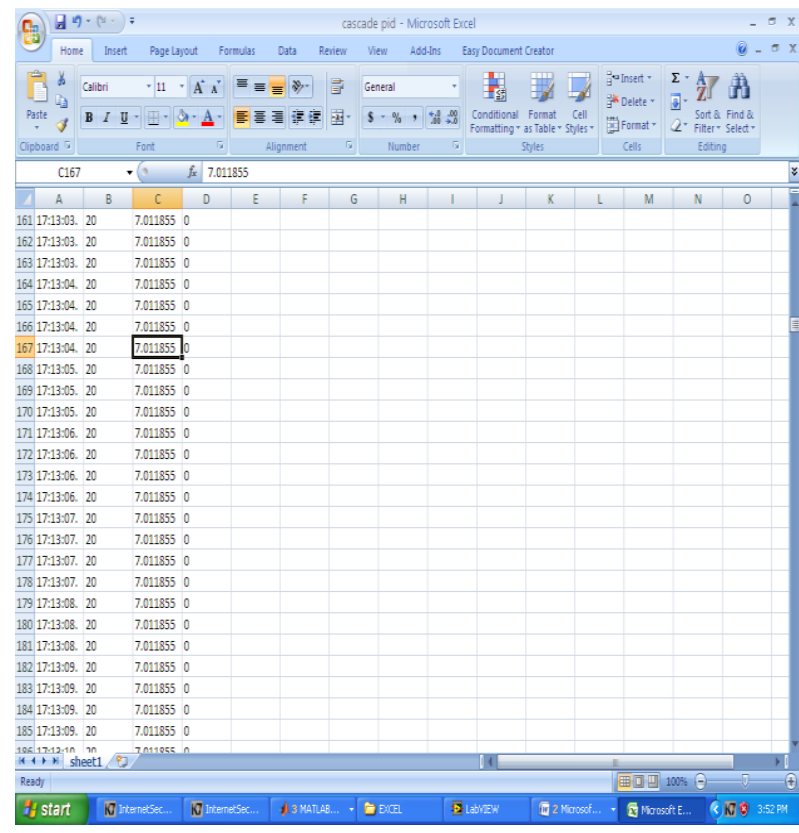

Figure 4 Excel Data format for the cascade Control System

\section{CONClusion}

Hereby we can conclude that the existing systems with convention methodologies and programming languages can be replaced with trending software's and technologies by just comparing and applying the algorithms of related process control. [19],[20],[21]

\section{REFERENCES}

1. Sharma, R.K., Irusapparajan, G. \& Periyaazhagar, D. 2019, "Three-phase symmetric cascading Z-source seven levels multilevel inverter excited by multi carrier sinusoidal pulse width modulation scheme", International Journal of Innovative Technology and Exploring Engineering, vol. 8, no. 10, pp. 4269-4274.

2. Velavan, R., Bharanidharan, S. \& Sheeba, B. 2019, "EMF pollution Causes, effects and protection", International Journal of Innovative Technology and Exploring Engineering, vol. 8, no. 9 Special Issue 3, pp. 1166-1168.

3. Saravana, S., Balaji, S., Arulselvi, S. \& John Paul Praveen, A. 2019 "Reliable power quality monitoring and protection system", International Journal of Innovative Technology and Exploring Engineering, vol. 8, no. 9 Special Issue 3, pp. 644-645.

4. Tamil Selvan, S. \& Sundararajan, M. 2019, "Performance Parameters of 3 Value 8t Cntfet Based Sram Cell Design Using H-Spice", International Journal of Recent Technology and Engineering, vol. 8, no. 2 Special issue 5, pp. 22-27.

5. Jac Fredo, A.R., Abilash, R.S., Femi, R., Mythili, A. \& Kumar, C.S. 2019, "Classification of damages in composite images using Zernike moments and support vector machines", Composites Part B: Engineering, vol. 168, pp. 77-86.

6. Kathiravan, P. \& Govindaraju, C. 2019, "Design and evaluation of ultra gain isolated DC-DC converter for photovoltaic system", International Journal of Engineering and Advanced Technology, vol. 8, no. 5, pp. 2646-2651.

7. Kripa, N., Vasuki, R. \& Kishore Kanna, R. 2019, "Realtime neural interface controlled au-pair BIMA bot", International Journal of Recent Technology and Engineering, vol. 8, no. 1, pp. 992-994.

8. Mohanraj, Meenaa Kumari, M., Philomina, S. \& Jasmin, M. 2019, "In-situ humidity measurement of hydrogen fuel cell car using MEMS sensor", International Journal of Recent Technology and Engineering, vol. 8, no. 1, pp. 41-43. 
9. Velmurugan, T. \& Prakash, S. 2019, "Artificial intelligent based distribution automation of swift fault detection isolation and power restoration for HT network", International Journal of Innovative Technology and Exploring Engineering, vol. 8, no. 6, pp. 1-6.

10. Dwarakesh, K. \& Prem Kumar, G. 2019, "Five-level inverter based sequential boost system using fuzzy logic controller", International Journal of Innovative Technology and Exploring Engineering, vol. 8, no. 6, pp. 12-19.

11. Anne Gifta, A. \& Hemavathi, G. 2019, "Analysis of grid tied solar PV system using ANFIS Algorithm", International Journal of Innovative Technology and Exploring Engineering, vol. 8, no. 6, pp. 312-316.

12. Jayavel, R., Rangaswamy, T.R. \& Prakash, S. 2019, "Efficient grid management system with renewable and conventional power sources", International Journal of Innovative Technology and Exploring Engineering, vol. 8, no. 6, pp. 287-289.

13. Hemavathi, G. \& Maheshwaran, S. 2019, "Proportional resonant controlled high gain step-up converter system with improved response", International Journal of Innovative Technology and Exploring Engineering, vol. 8, no. 6, pp. 317-323.

14. Periyaazhagar, D. \& Irusapparajan, G. 2019, "Design and completion of asymmetric single phase 27 level cascaded mli for various pwm scheme", International Journal of Innovative Technology and Exploring Engineering, vol. 8, no. 6, pp. 792-797.

15. Mahalakshmi, V. \& Vijayaragavan, S.P. 2019, "PV based power electronic converters for high voltage DC applications", International Journal of Recent Technology and Engineering, vol. 7, no. 6, pp. 670-674.

16. Irusapparajan, G., Periyaazhagar, D., Prabaharan, N. \& Rini Ann Jerin, A. 2019, "Experimental verification of trinary DC source cascaded h-bridge multilevel inverter using unipolar pulse width modulation", Automatika, vol. 60, no. 1, pp. 19-27.

17. Sangeetha, G., Sherine, S., Arputharaju, K. \& Prakash, S. 2019, "On Line Monitoring of Higher Rated Alternator using Automated Generator Capability Curve Administer", Proceedings of the IEEE International Conference on \&amp;quot;Recent Trends in Electrical, Control and Communication\&amp;quot;, RTECC 2018, pp. 176.

18. Bycil, V.J. \& Wiselin, M.C.J. 2019, "Modeling and analysis of vibration energy harvesting system using piezo stack", International Journal of Mechanical and Production Engineering Research and Development, vol. 9, no. Special Issue 1, pp. 523-533.

19. Sripada, A., Warrier, A., Kapoor, A., Gaur, H. \& Hemalatha, B. 2018, "Dynamic lateral balance of humanoid robots on unstable surfaces", International Conference on Electrical, Electronics, Communication Computer Technologies and Optimization Techniques, ICEECCOT 2017, pp. 539.

20. Srinivasan, S., Thirumalaivasan, K. \& Sivakumaran, T.S. 2018, "Performance evaluation of double-output luo converters", Journal of Advanced Research in Dynamical and Control Systems, vol. 10, no. 10 Special Issue, pp. 870-878.

21. Karthikayen, A. \& Selvakumar Raja, S. 2018, "A skellam distribution inspired trust factor-based selfish node detection technique in MANETs", Journal of Advanced Research in Dynamical and Control Systems, vol. 10, no. 13, pp. 940-949.

\section{AUTHORS PROFILE}

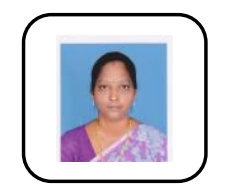

B.Kalaiselvi, Assistant Professor, Department of EIE,Bharath Institute of Higher education and research, Tamilnadu, India

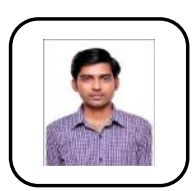

T.Vijayan, Assistant Professor, Department of EIE,Bharath Institute of Higher education and research, Tamilnadu, India.

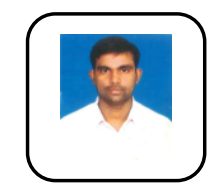

Sridhar raja D, Assistant Professor, Department of EIE,Bharath Institute of Higher education and research, Tamilnadu, India.

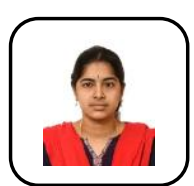

R.Abinethri, Assistant Professor, Department of EIE,Bharath Institute of Higher education and research, Tamilnadu, India 